\title{
イメージオルシコン排気工程での マルチプライヤー利得測定法
}

NHK 総合技術研究所河村達郎

\begin{abstract}
分割形アセンブリーの考案と直流偏向測定佉の採用によって，排気工程中の利得測定か可能とな り，マルチプライヤー利得に，佸性化処理，再活性化処理，七シウム蒸着の各工程の影響が大きい ことか確かめられた また，測定によって，乙れらの工程についての定量的な検討か容易となり， 処理方去の改良なと，利得向上をはかる大きな手段となった
\end{abstract}

\section{1. え がき}

イメージオルシコンは，テレビジョン放送用の撮像管 として最も多く使用されているか, 放送技術の進展とと むに，その撮像管に対する要求むきわめて強いあのがあ り，画質の向上，高感度化等の諸特性改善についての研 究か進められてきている てれらの研究成果とあいまっ て,イメージオルシコンの製作技術も次第に進歩確立さ れてきた

実際の製作過程ては，100 種類にもおよふ部品材料と 細心の住意を要する数多くの工程かあるか，特に排気工 程は，その工程中に㓌極と 2 次電子面の活性化や光電面 製作なとの一連の作業かふくまれ，イメーシオルシコン の画質, 特性を大きく左右する工程として, きわめて重 要視される一方, この工程中の作業については, 製作 者の長年の経験に基つくところか多く，定量的に明らか にされていない部分か少なくない

イメージオルシコンの信号出力電充に関係するマルチ プライヤー利得についても, 従来は, その素材てある $\mathrm{Ag}-\mathrm{Mg}$ 合金の佸性化法に関する研究か多く行なわれて きたか, その研究結果とマルチプライヤー利得との対応 か困難てあった これは, 実際のイメーシオルシコンて は，構造上の問題に加えて，周囲の影響を骎けやすい 2

\section{筆 者 紹 介}

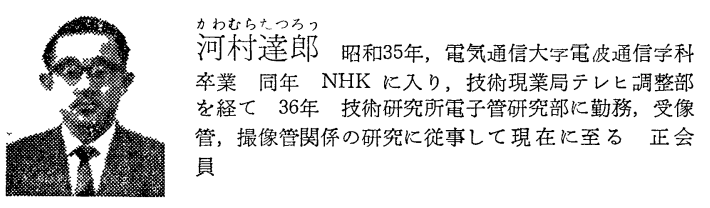

"Multıplier Gain Measurements of Image Orthicon durıng Evacuat ion Process" by Tatsuro Kawamura (NHK Technical Research Laborator1es, Tokyo)，テレビ用電子管研究委員会発表（昭39 11）
次電子面か数多くの工程を経るためてあり, 途中の工程 てのマルチプライヤーの状態を, 何らかの方佉て定量的 につかむととか必要てあった

筆者は，一つの手段として，困難とされていた測定方 法に検討を加え，测定装置の試作により，排気工程中て のマルチプライヤー利得の測定を試みた 以下，排気工 程について概説を行ない, 测定装置の概要と測定方法, 得られた測定結果について報告する

\section{2. 排 気 工 程}

イメージオルシコンの全製作工程については，渡辺の， 資料にくわしいが，凶1は，乙のうち特にマルチプラ イヤーについて取り上げ，2 次電子面材籵からイメージ オルシコンとして製作されるまての工程を表わしたもの てある 測定対象としている排気工程は，イメーシ部をすてに取り付けすみのカラス外管にマルチプライヤーを 封し込み, 排気台に取り付けてから，イメーシオルシコ ンとして封止されるまての工程全体を指し，その中には 幾つかの工程かふくまれる

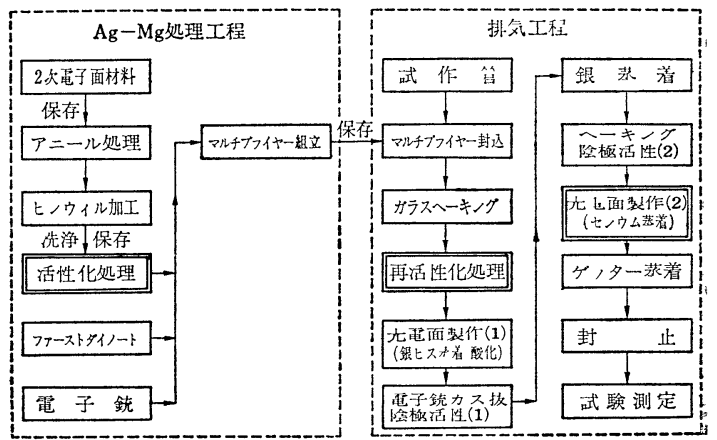

冈1 マルチプライヤーについてのイメーシ オルノコン製作工程 
排気工程中での処理方法いかんによって，管の性能，特 性は大きく左右されるが，マルチプライヤー利得につい て見れば，管に封じ込む前に行なわれる活性化処理と， 排気工程中の再活性化処理およびセシウム蒸着の各工程 の影響が大きいと考えられてきた。

\section{1 活性化処理}

イメージオルシコンのマルチプライヤーは， 5 段の 2 次電子面から成り, 各段の 2 次電子放出比 $\delta$ が 1 より大 きいのを利用して，高い総合倍率により微小信号電流の 増倍を行なうものである.

周期律表第 2 属の $\mathrm{Be}, \mathrm{Mg}, \mathrm{Ca}, \mathrm{Ba}$ 等を数\%ふくむ合 金を，適当な酸化雾囲気中で熱処理すると（乙れを活性 化処理と呼ぶ）, $\delta$ の高い 2 次電子面が得られるととはよ く知られている. イメージオルシコンのマルチプライヤ 一の場合には，その 2 次電子面として，面の均一性を厳 しく要求される第 1 ダイノードを別として， 2 段から 5 段までは $\mathrm{Ag}-\mathrm{Mg}$ 合金を使用し，その選択酸化によって 形成される $\mathrm{MgO}$ の面の $\delta$ を利用している.

実際にイメージオルシコンを製作する場合，マルチプ ライヤーを管に封じ込み後に活性化処理を行なうには， 光電面製作への影響から排気工程の最初に行なわなけれ ばならず，高周波加熱による場合は，マルチプライヤー の構造上， 2 次電子面の一様性が望めないとと，炉加熱 による場合は，温度に制約を受けるととままた，他の電 極への影響むあって，選択酸化の条件を自由に選べない などの理由から，実用上，ピンウィルの形であらかじめ 充分な処理を行なっておき，マルチプライヤーに組み立 て，管に封じ込み後では，簡単な方法で再活性化すると いう方法を採用している。

ここで, 封じ込み前の処理を活性化処理 (Pre-Activation) 之呼び, 後の処理を再活性化処理 (Re-Activation) と呼ぶ. 活性化処理の方法をどのようにするかは，マル チプライヤー利得に大きな関係があり, 選択酸化の条件 については幾つかの研究発表があるが231, 常に安定した 状態で活性化できること，そのコントロールが容易であ ること, 活性面の $\delta$ の值が大きいととが必要である.

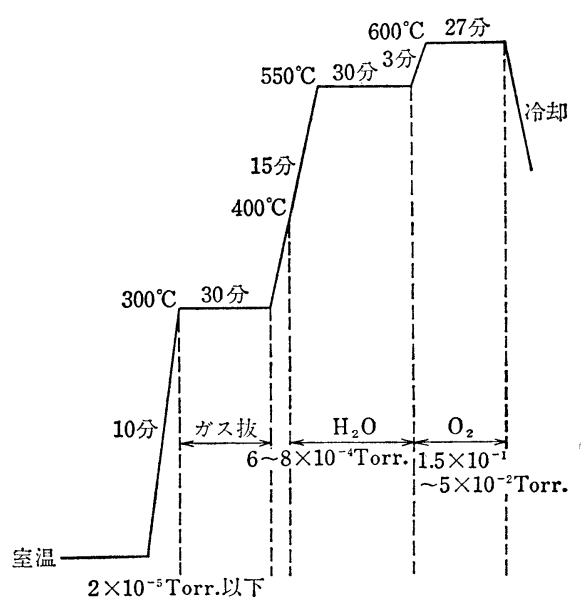

図 2 活性化処理

囲の状態，組み立て後の保存法には充分な注意が必要で あり，保存期間の短縮が望まれる。乙の減衰は，排気工 程の最初に行なわれるガラスベーキング $\left(385^{\circ} \mathrm{C}, 60\right.$ 分 $1 \times 10^{-5}$ Torr. 程度)によって，ある程度まで回復するす の之みられる. 以下, ガラスベーキング後のマルチプラ イヤー利得の值を初期值と呼ぶ.

初期值は，電子ビームに対するマルチプライヤーの構 造上の効率や活性化処理の方法, あるいは保存法などに 左右され, 初期值の低いものでは最終的に高利得を望み 得ない. マルチプライヤー利得についていえば，セシウ 么蒸着によって利得の著しい増加が見られるが，さらに 利得の向上をはかる意味から, ガラスベーキング直後に 再活性化処理を行なう。

図 3 亿ガラスベーキングと再活性化処理の過程を示す. 再活性化処理については, まだ検討する余地があるが, 現 在はマルチプライヤー部分のみ加熱するような小さな炉 をかけ(マルチ炉と呼ぶ), 過マンガン酸カリを熱して発 生する酸素ガスを利用して処理する方法を取っている.

\section{3 セシウム蒸着}

マルチプライヤー利得は，七シウム蒸着によって急激 に上昇する，乙の現象がどのような機構のもとで生ずる
図 2 は筆者が採用している活性化 処理の一方法を示す.

\section{2 再活性化処理}

活性化処理後, ピンウィルはマル チプライヤー組み立てのため大気中 ルさらされるが, 主として各種のガ スなどの物理的吸着, および水分之 の反応による $\mathrm{MgO}$ から $\mathrm{Mg}(\mathrm{OH})_{2}$ への変質などがあって, $\delta$ の值は減 衰する. このため, 組み立て時の周

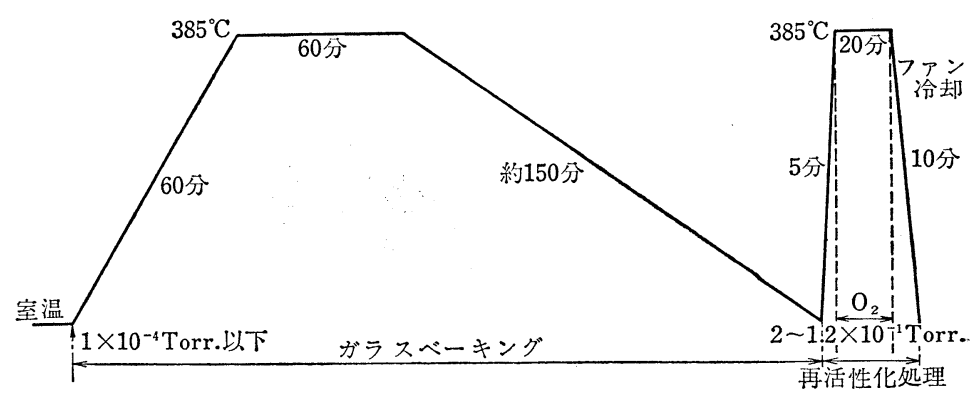

図 3 ガラスベーキングと再活性化処理 
のかはまだ明らかにされていない，また，利得が 㣘上するという定性的な考え方はあったが, 定量 的な面は明らかでなかった，実際のセシウム蒸着 の工程では, 光電面製作やターゲットへの効果を 主体として行なわれるので，マルチプライヤーと しては，光電面やターゲットへのセシウム量のコ ントロールに対応して，セシウム蒸着中にはマル チ炉をかけ，炉の温度 $\left(200 \sim 250^{\circ} \mathrm{C}\right)$ によって，付 着するセシウム量をコントロールする方法をとっ ている.

一般に，マルチ炉の温度を下げるととで，マル チプライヤーへのセシウム蒸着量は増加する傾向 《あり，その温度は， $S N$ 比およびマルチプライ ヤー利得の向上, リーク電流の軽滅などを考慮し て決定される.

\section{3. 利得測定装置の試作}

\section{1 測定上の問題点}

マルチプライヤー利得の測定には, 幾つかの問題点が あり，測定值の再現性と信頼度の高いものが得られがた い，また，测定法としては，画像を最良に調整した状態 で, 動的に測定することが望ましいが，ここでは排気工 程中に測定するという特殊な場合であるとと，また，工 程中の状態をできるだけ明らかにするために, 総合利得 だけでなく, 各段の $\delta$ の測定も必要であることなどを考 慮しなければならない，まず，測定対象であるイメージ オルシコンが排気台に取り付けられている関係から，

（1）排気中の管は, 直径 $12 \mathrm{~mm}$ 程度のガラス管(チ ップ管）によって排気系に接続, 支持されており, この状態でアセンブリーを装着しなければならない こと.

（2）工程中に数回測定を行なうため, アセンブリー の着脱が容易であるてと.

などの制約に加えて，一般的には，

（3）取り扱うビーム電流が $10^{-8} \mathrm{~A}$ 程度の微小電流 であり, 回路の誘導やリークが測定值に影響を与え やすい.

（4）マルチプライヤー入力としての 1 次ビームの直 接測定が困難であり, その值の精度によって利得の 算出值が大きく左右される.

などの問題がある.

\section{2 試作測定装置}

測定に際しての幾つかの問題点と制約を考慮し, 装置 として，やや簡単な構成にできる静的な測定法) を採用 した. この測定法は, ターゲットに向かう電子ビームに 対して直流偏向をかけ， $G_{4}$ 電極に流れ込む電流值をむっ

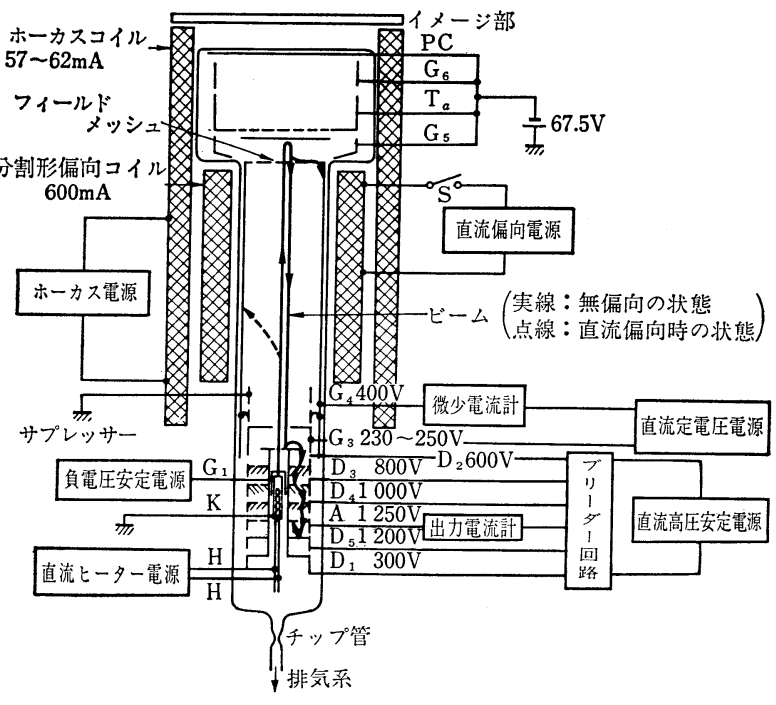

図 4 测定装置系統図

て, 正常動作時のマルチプライヤーへの入力 1 次ビーム の測定值としているとてろから, 直流偏向法上呼んでい るものである. 図 4 に測定装置系統図を示す．装置につ いては,

（1）その安定度と精度が厳しく要求されるため, 回 路の誘導やリークの防止をはかって, 配線には絶縁 性の良いポリエチレン線やシールド線を使用する一 方, 電源はすべて安定化電源を用いた。

（2）工程中の测定という特殊な状態を考慮して，分 割形アセンブリーを考案試作した。

分割形アセンブリーは，乙の測定のため特に製作した もので，ホーカスコイルと分割偏向コイルから成る. ホ 一カスコイルは, 普通のオルシコンアセンブリー中でも 最む重い部分であり，乙の重みをチップ管にかけるとと はできないので，特に支持具を作り，管とコイルとの相 対位置を規定するとともに，管上部からホーカスコイル のみを単独にはめるようにした，分割偏向コイルは，水 平偏向用コイルを利用し，シールドの方法に改良を加え て全体を 2 分割している。 また, 静的な方法では, 計器 の指示によりビームのアライメントを判定することは不 可能に近く, アライメントコイルは使用していない.

ホーカスコイルの電流値は, あらかじめ普通のオルシ コンアセンブリーとして使用したときの最適值を求めて おいたが，実際には，排気台上では管とホーカスコイル との相対位置が，オルシコンの取付け方によって多少ず れるここがある.このため, 測定する場合には，それぞ れ調整を要するが, 一般には出力電流最大值とホーカス 電流の最適值がほぼ一致するすのと見てよい.

\section{3 測 定 法}


排気工程には幾つかの工程が ふくまれ，それらの処理によ って陰極面が污染されるので 測定に先立って，必ず陰極活 性の処理を行なわねばならな い. 実際の測定は以下のよう に行なう.

(1) 排気中のイメージオ ルシコンに分割形アセンブリ 一を装着し, 測定装置からの 配線によって規定の各電圧を 与え, 次にビームを流す。な お，イメージ部には図 4 に示 すように，電池によりカソー ドに対して負電圧をかけ，ビ 一ムを強制的にマルチプライ ヤ一側に追い返すようにして ある。

（2）直流偏向により，ビ 一ムを $G_{4}$ 電極側に偏向させ 流れ込む電流をむって，マル チプライヤーへの入カビーム 電流值とする，乙の值は，実 際に撮像管として動作させる 状態に近づけるため $0.05 \mu \mathrm{A}$ 程度に調整する。

（3）偏向を止め，ビームをターゲットから追い返し 増倍させて出力電流を読み取る. このとき, 出力電流が 最大となるよう $\mathrm{G}_{3}$ 電圧を調整する，乙の電流值を先に 求めた 1 次ビーム電流值で除すると, マルチプライヤー の総合利得 $\Delta_{5}$ が得られる.すなわち, 直流偏向時の $\mathrm{G}_{4}$ 電流を $I_{4^{\prime}}$, 出力電流を $I_{0^{\prime}}$ とし, 無偏向時の值をそれぞ 机 $I_{4}, I_{0}$ とすると，

である.

$$
\Delta_{5}=\frac{I_{0}-I_{0^{\prime}}}{I_{4}^{\prime}-I_{4}}
$$

ここで $I_{0}{ }^{\prime}$ と $I_{4}$ は, リーク電流の補正の意味をむつ が，フィールドメッシュ入りの管の場合には，メッシュ の透過率とサプレッサーグリッドの影響があって， Io, $I_{4}{ }^{\prime}$ にそれぞれ近い值にまで大きくなり，無視できない， $\Delta_{5}$ は，5段までの総合利得を示すが，4 段までの利得 $\Delta_{4}$ が求めたいときは，ロータリースイッチの切り換えによ り，アノード電圧も第 5 ダイノード電圧と同じ $1200 \mathrm{~V}$ と し，流れる電流を出力電流とすれば，上式を利用して $\Delta_{4}$ が得られる. 同様に，各段までの利得がそれぞれ求めら れ， $\Delta_{5} / \Delta_{4}$ によって第 5 ダイノードの $\delta$ が $\left(\delta_{5}\right.$ とする $)$,
表 1 測定結果 (1)

\begin{tabular}{|c|c|c|c|c|}
\hline \multicolumn{2}{|c|}{ 気 } & 和 & 2 & \multirow[b]{2}{*}{ 備 } \\
\hline 学活性化 & 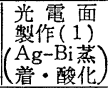 & $\begin{array}{l}\text { 電子銃 } \\
\text { ガス抜き }\end{array}$ & 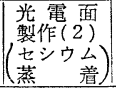 & \\
\hline - & 1.05 & 0.66 & 1.90 & \multirow{7}{*}{$\begin{array}{l}\text { 1) } 5820 \text { 形実験管 } \\
\text { (ガラスターゲット) } \\
\text { 2) 活性化処理 } \\
\mathrm{O}_{2} 1 \times 10^{-3} \text { Torr. } \\
550^{\circ} \mathrm{C} \quad 10 \text { 分 } \\
700^{\circ} \mathrm{C} \quad 3 \text { 分 }\end{array}$} \\
\hline - & 3. 45 & 4. 34 & 4.11 & \\
\hline - & 2. 37 & 1.81 & 3.43 & \\
\hline - & 2. 42 & 2. 22 & 3.08 & \\
\hline- & 3. 45 & 4. 32 & 4. 47 & \\
\hline \multirow[t]{2}{*}{ - } & 72 & 75 & 379 & \\
\hline & & & 3.94 & \\
\hline 1.14 & - & 0.91 & 2.54 & \multirow{2}{*}{ 1) $\begin{aligned} 5820 \text { 形実験管 } \\
\text { (ガラスダット) }\end{aligned}$} \\
\hline 3. 38 & - & 4. 66 & 4.56 & \\
\hline 2. 36 & - & 2. 36 & 2.76 & \multirow{2}{*}{$\begin{array}{l}\text { 2) 活性化処理 } \\
\mathrm{O}_{2} 2.5 \times 10^{-1} \text { Torr. } \\
600^{\circ} \mathrm{C} \quad 10 \text { 分 }\end{array}$} \\
\hline 1.76 & - & 2. 39 & 2. 92 & \\
\hline 3. 80 & - & 3. 47 & 4. 40 & \multirow{3}{*}{$\begin{array}{l}\text { 3) 再活性化処理 } \\
\mathrm{O}_{2} 1 \times 10^{-2} \text { Torr. } \\
500^{\circ} \mathrm{C} \quad 5 \text { 分 } \\
\text { (高周波加熱による) }\end{array}$} \\
\hline 61 & - & 83 & 411 & \\
\hline & - & & 4. 27 & \\
\hline - & 1.03 & 1.09 & 1.50 & \multirow{7}{*}{$\begin{array}{l}\text { 1) } 5820 \text { 形実験管 } \\
\text { (ガラスターゲット) } \\
\text { 2）活性化処理 } \\
\mathrm{O}_{2} 2.5 \times 10^{-1} \text { Torr. } \\
550^{\circ} \mathrm{C} \quad 10 \text { 分 }\end{array}$} \\
\hline- & 3. 50 & 3. 81 & 5.00 & \\
\hline - & 2.65 & 2.84 & 3. 58 & \\
\hline - & 2.76 & 2.82 & 3.91 & \\
\hline - & 3. 31 & 3. 41 & 4. 81 & \\
\hline - & \multirow[t]{2}{*}{87} & \multirow[t]{2}{*}{114} & 505 & \\
\hline- & & & 5.04 & \\
\hline - & - & 1.43 & 2.12 & \multirow{2}{*}{ 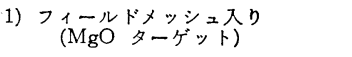 } \\
\hline- & - & 2.50 & 3.77 & \\
\hline - & - & 2. 30 & 3.89 & \multirow{2}{*}{$\begin{array}{l}\text { 2) 活性化処理 } \\
\mathrm{O}_{2} 2.5 \times 10^{-1} \text { Torr. } \\
550^{\circ} \mathrm{C} \quad 10 \text { 分 }\end{array}$} \\
\hline- & - & 2.74 & 2.57 & \\
\hline- & - & 3.81 & 7.30 & 3) 七シウム蒸着時マルチ炉使用 \\
\hline - & - & 86 & 583 & $\begin{array}{l}\text { 4) 多一ゲット破損のため信号電流湘 } \\
\text { 定能 }\end{array}$ \\
\hline
\end{tabular}

以下, $\delta_{4} \sim \delta_{1}$ が算出される.

一般に，マルチプライヤー利得を測定すると，その值 にはかなり広いばらつきが見られる。これはもちろん， 測定装置の安定度にあよるが,

（1） 2 次電子面の処理条件を，全工程を通じて常に 一定に保つととが非常にむずかしいとと.

（2） 総合利得が各段の $\delta$ の相乗積としてきいてくる とてろから，わずかな処理条件の違いによって生ず る各段 $\delta$ の小さな差が大きく影響するとと. などからくる。

\section{4. 測 定 結 果}

表 1 , 表 2 亿測定結果を示す. 備考欄に活性化処理, 再活性化処理について特に記してないあのは，それぞれ。 図2, 図 3 の方法によっている. 表中には, 各段の $\delta$ 之 総合利得 $\Delta_{5}$ 亿ついて, 初期值および各工程での值が示 されている．また図 5 に工程中の利得推移を示した．乙 こで, 信号出力電流は，管封止後の試験測定により測定 されるが，マルチプライヤー利得の值によってのみきま るものではなく，ターゲットよターゲットメッシュのス ペース間隔による蓄積容量, あるいは, フィールドメッ 
表 2 测 定結 果 (2)

\begin{tabular}{|c|c|c|c|c|c|}
\hline \multirow[b]{2}{*}{ 管番号 } & & 排 & \multicolumn{2}{|c|}{ 工 程 } & \multirow[b]{2}{*}{ 備 } \\
\hline & & 初 期 值 & $\begin{array}{l}\text { 再活性化 } \\
\text { 处 理 }\end{array}$ & $\left.\mid \begin{array}{cc}\text { 光 電面 } \\
\text { 製作 }(2) \\
\text { ゼウ } \\
\text { 蒸 } & \text { 着 }\end{array}\right)$ & \\
\hline \multirow{7}{*}{ No. 5} & $\delta_{1}$ & 1.08 & 1. 28 & 2.08 & \multirow{7}{*}{$\begin{array}{l}\text { 1) フィールドメッシュ } \\
\text { 人り } \\
\text { (MgO ターゲット) } \\
\text { 2) セシウム蒸着時マル } \\
\text { チ归使用 }\end{array}$} \\
\hline & $\delta_{2}$ & 4.75 & 5.54 & 7.81 & \\
\hline & $\delta_{3}$ & 3. 33 & 3. 31 & 5.42 & \\
\hline & $\delta_{4}$ & 2.84 & 3. 24 & 5.01 & \\
\hline & $\delta_{5}$ & 4.82 & 4. 64 & 5.63 & \\
\hline & \multirow{2}{*}{ 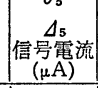 } & \multirow[t]{2}{*}{232} & \multirow[t]{2}{*}{352} & 2480 & \\
\hline & & & & 13.3 & \\
\hline \multirow{7}{*}{ No. 6} & \multirow{7}{*}{$6\left|\begin{array}{c}\delta_{2} \\
\delta_{3} \\
\delta^{4} \\
\delta_{5} \\
\Delta_{5} \\
\text { 信号電流 } \\
(\mu \mathrm{A})\end{array}\right|$} & 1.14 & 1.43 & \multirow{2}{*}{$\begin{array}{l}2.05 \\
8.98\end{array}$} & \multirow{7}{*}{$\begin{array}{l}\text { 1) フィールドメッシニ } \\
\text { 入り } \\
\text { (MgO ターゲット) } \\
\text { 2) セシウム蒸着時マル } \\
\text { 千炉使用 }\end{array}$} \\
\hline & & 5.67 & 4. 66 & & \\
\hline & & 3.00 & 3. 74 & 4.82 & \\
\hline & & 3.04 & 2. 89 & 4.81 & \\
\hline & & 4.01 & 4. 01 & 4.52 & \\
\hline & & 236 & \multirow[t]{2}{*}{288} & \multirow{2}{*}{$\begin{array}{l}1925 \\
9.18\end{array}$} & \\
\hline & & & & & \\
\hline \multirow{7}{*}{ No.7 } & $\delta_{1}$ & \multicolumn{2}{|c|}{1.17} & 1.95 & \multirow{7}{*}{ 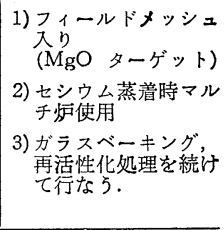 } \\
\hline & $\delta_{2}$ & \multicolumn{2}{|c|}{ 5. 39} & 8.00 & \\
\hline & $\delta_{3}$ & \multicolumn{2}{|c|}{ 3. 25} & 4. 79 & \\
\hline & $\delta_{4}$ & \multicolumn{2}{|c|}{3.72} & 4.99 & \\
\hline & $\delta_{5}$ & \multicolumn{2}{|c|}{4.82} & 5.58 & \\
\hline & $\Delta_{15}$ & \multirow{2}{*}{\multicolumn{2}{|c|}{369}} & 2080 & \\
\hline & $\mid \begin{array}{c}\mid \begin{array}{c}1 \\
(\mu \mathrm{A})\end{array} \\
\text { 電流 }\end{array}$ & & & 13.2 & \\
\hline
\end{tabular}

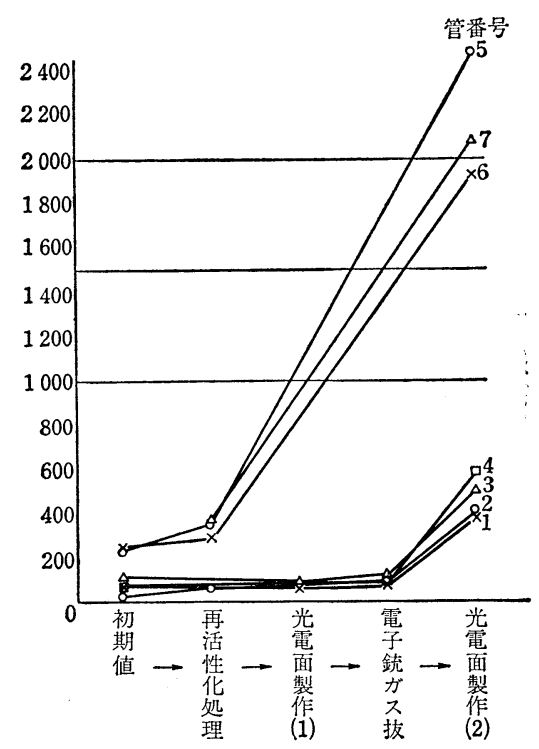

図 5 排気工程中のマルチプライヤー 利得推移

シュの使用いかんによって，その透過率にも関係してく るあのである.

一般に，スペース間隔が狭ければ，蓄積容量の増加に よって，信号出力電流が増し，同時に $S N$ 比む向上する が，製作技術上の問題から制約されている.また，フィ 一ルドメッシュは, 出力電流から考えれば, 目の粗く, 透過率の大きいあのが望まれるが，ターゲットメッシュ
間とのビートパターン発生の問題もあり，それらを考虑 して決定される.

たとえば，5820形のイメージオルシコンでは，ターゲ ットスペースは普通 $50 \mu$ ，蓄積容量は約 $100 \mathrm{pF}$ である.

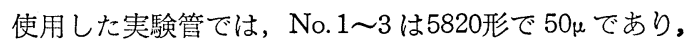

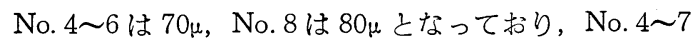
はいずれもフィールドメッシュとして 750本/in のメッ シュを使用し，その透過率は約 $56 \%$ である.

一般に, マルチプライヤー利得としては, 以上述べた スペース間隔や，フィールドメッシュの有無などを考慮 しなければならないが, 充分な出力電流を得るためには, 5820 形の管で 1000〜1500 倍，フィールドメッシュ入り の管では 1500～2000 倍が要求される.

\section{5. 検討}

管の製作において工程中の状態を把握することは，工 程管理の上からいっても，また特性の改善をはかる資料 を得るためにも非常に重要である，乙こで取り上げた排 気工程中の利得測定も, その必要性にかかわらず, 测定 の困難さのゆえに試みられたてとがなかったが，測定装 置の試作により, 工程中の利得推移を定量的につかむと とむに，測定值の検討によって，幾つかの事象を見いだ すととができた。

（1）排気工程中において, マルチプライヤー利得に 大きな関係をむつものは，

(a) ガラスベーキング後の初期值

(b) 再活性化処理

(c) セシウム蒸着

であるととが確認されたが，てれは従来の経験を裹づけ ている. 一方, 銀一ビスマス蒸着・酸化, 電子銃ガス抜 き，銀蒸着等の工程では，あまり影響がないものと見て よい，特に，電子銃ガス抜きの工程は，高周波加熱によ るその高温によって, マルチプライヤーの再活性化作用 が行なわれるという考え方があったが，測定によれば， 多少の増加があるときす見られるが，逆に減少する場合 ああり, 平均して見ると, その再活性化作用を認めがた い.

（2）マルチプライヤーの各ダイノードの $\delta$ の值を見 ると $\delta_{1}$ が最む低く, $\delta_{3}, \delta_{4}$ が $\delta_{2}, \delta_{5}$ に対してやや低い. ここで，第 1 ダイノードは， $\delta$ の減衰が小さいことや， 面の均一性が良いととが厳しく要求され， $\delta$ の值をある 程度犠牲にして，その材質をきめている. 現在はAg に $\mathrm{Cr}$ を蒸着したクロムダイノードが使用され， $\delta_{1}$ として 1.5〜2.5 程度しか得られないが，マルチプライヤー利 得だけでなく $S N$ 比向上のためにも， $\delta$ の高い第 1 ダイ ノードについての検討が必要亡思われる. 
$\delta_{3}, \delta_{4}$ が $\delta_{2}, \delta_{5}$ にくらべて低いのは，マルチプライヤ 一の構造的な問題と考えられる. $\delta_{5}$ は最終段でピンウィ ル形状でないため効率的に有利であり， $\delta_{2}$ は他の段より 電圧が高く，一般に最む高い $\delta$ 值を示す.

（3）初期值向上のために種々の活性化処理を行なっ てみた結果, 図 2 の方法を採用した. また, ピンウィル の角度の補正, 有効面種の増加をはかって, ピンウィル 打ち抜き加工用の新しい型を設計製作した，表 1 の実験 管(No. 1 4) と表 2 の実験管 (No. 5〜6)で，初期值に大 きな差が見られるのは，乙の打ち抜き用型の違いが現わ れたものであり，マルチプライヤーの構造上の影響が大 きいととがわかる。

（4）再活性化処理の一方法として, 実験管 No. 2 に 行なったように，高周波加熱によるものがある．短時間 で行なえることや，利得のかなりの増加が望めるなどの 利点があるが, 他の電極も酸化して外観を損ね, カソー ドへの影響などを若慮すると好ましくない，一方，マル 于炉による再活性化処理は, やや時間が長く, 初期值か らの利得増加もそれほど大きくないが，セシウム蒸着前 の利得を少しでも上げておくことは大きな意味があり， この工程を省略することはできない．

（5） セシウム蒸着時にマルチ炉を使用しない場合に は, 蒸着前にくらべて 4. 5 5 倍の利得増加が見られる. マルチ炉の使用により，七シウム量のコントロールをは かると6〜 7 倍となり, 炉の効果が認められる. また, $S N$ 比む向上するととが確かめられている.

（6）工程中の利得推移加みて, 初期值として 200 〜250 倍, 再活性化処理後で 300〜400 倍となれば, セシ ウム蒸着後の最終的な利得として 2000 倍前後が期待で き,フィールドメッシュ入りの管でも充分な信号電流を
得るととができる.

\section{6.むすび}

排気工程中の各段階での利得変化を, 種々の条件のむ とで測定してきたが, 利得の向上のためには, まず, 初 期值を上げておくこと, 次に, セシウム蒸着前の利得を できるだけ高めておくことが必要なととが明らかにされ た. これとともに, 活性化処理, 再活性化処理, セシウ ム蒸着などについて, 定量的な検討のための糸口をつか むととが容易となり，マルチプライヤー利得向上のため の大きな手段となった.

今後の課題之して, 現在, 第 1 ダイノードについての 検討がまだ不充分であり, 利得增加, $S N$ 比向上をはか る一つの方法として, 重要な問題であると考えられる. また，利得増加の機構については，まったく検討が行な われて抢らず，た之えば，セシウム蒸着の際の現象の解 明など大きな問題が残されている.

終わりに，激励を賜わった吉永電子管部長，二宮副部 長, 終始助言と協力をいただいた電子管試作研究室渡辺 技師，立谷，畠山職員に湅く感謝する，また，実験管の 製作をしていただいた電子管試作研究室の方々，試験測 定をされた撮像管研究室小林職員に謝意を表する.

(昭和 40 年 2 月 5 日受付)

\section{〔参考文 献〕}

1) 渡辺：イメージオルシコンの製作，テレビ誌，17(1963) 235〜242

2) P. Rappaport: Methods of Processing Silver-Magnesium Secondary Emitters for Electron Tubes, J. Appl. Phys., 25 (1954) $288 \sim 292$

3) M. Hirashima: Selective Oxidation of Silver-Magnesium Alloys in Water Vapor, J. Phy. Soc. of Japan, 10 (1955) 1055 1064

4) 高橋, 小川：イメージオルシコンの電子堌倍部綜合利得の測定, 昭和 30 年電気学 3 学会連合大会, 702

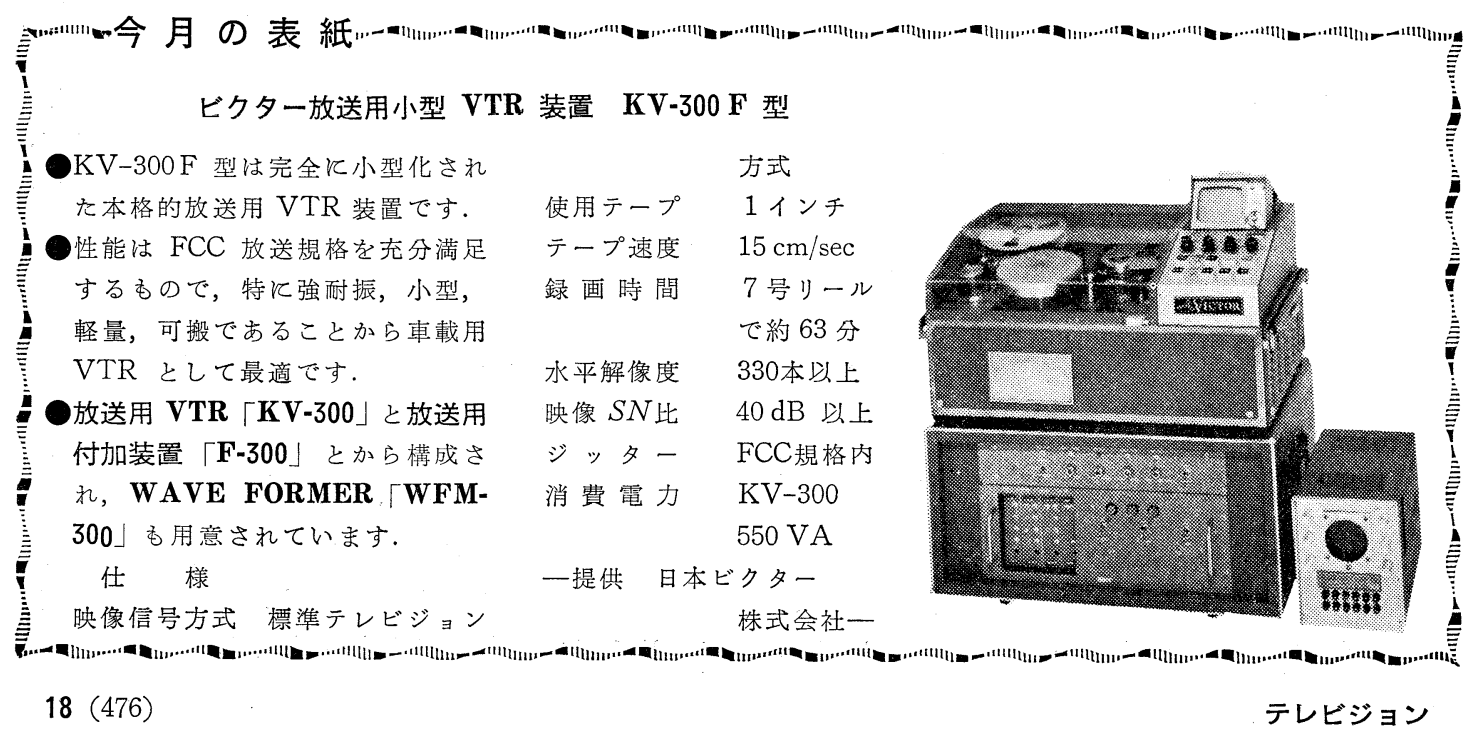

